\title{
Mobile Educational SMSs as Supplementary Means to Teach Sentence Paraphrasing in EMP Course
}

\author{
http://dx.doi.org/10.3991/ijim.v10i1.5188 \\ Jafar Asgari Arani \\ Kashan University of Medical Sciences, Kashan, Iran
}

\begin{abstract}
Digital media has been used to enhance language learning for decades. Since the aim of language learning is to develop communicative proficiency, using communication devices and channels that already exist in the classroom is a sensible way of exploiting opportunities for language practice. The 'anywhere, anytime' accessibility to educational contents that mobile SMSs, sometimes freely, offer users, means that mobile learning can extend the opportunities for study outside of the classroom. Given the importance of writing, especially for academic purposes in university, the study set a dual goal: firstly, to analyze the outcome of applying supplementary SMS activity to teach English syntax necessary to paraphrase sentences and secondly, to clarify the medical students' ideas about it.
\end{abstract}

A quasi-experimental, pre-test and post-test, research design was utilized to investigate the hypotheses of this study. Two groups (each 40-second year students of medicine) were randomly assigned to be the experimental and the conventional group. Both groups were taught the same syllabus materials designed for English for Medical Purposes (EMP) II course in a 17-week semester in Kashan University of Medical Sciences, Iran. The former received the SMS -based supplementary contents in a scheduled pattern of delivery two times a week to strengthen their learning while the latter only was taught in a face to face setting. An open questionnaire was used to examine students feedback towards their attitudes. The validity of the questionnaire was examined by giving to a number of professors of English language. The data were also collected and analyzed through an Attitude/ Motivation questionnaire consisting of 12 Likert-scale items, pretest\& posttest, paired-samples ttests, and one way ANOWA.

The pretest and posttest data paired t-test likert-scale items analyzed results showed that differences between the experimental and control groups were statistically significant. It was found that the effect of practicing SMS on the students' English syntax learning was positive. According to the findings, students receiving the supplementary English syntax SMSs noticeably improved their sentence paraphrasing performance and acquired higher grades during the posttest than those in conventional group. Qualitative data from interviews and questionnaires indicate that students hold positive attitudes towards receiving paraphrase syntactic points via SMS. Majority of students in this pilot project considered the educational program offered to be efficient, useful and beneficial. The data gathered revealed mobile syntactic supplementary SMSs can be integrated into EMP II course to enable students to develop better English sentence paraphrasing skills.
Index Terms-Mobile SMS; Sentence Paraphrasing; Educational Tool; English for Medical Purposes

\section{INTRODUCTION}

With its widespread use and its features and functions such as mobility, reachability, localization, and personalization, mobile phone technology may lead to positive effects in learning environments. Using mobile phones in educational settings will help learners be more motivated and will make it possible to overcome the difficulties teachers experience in order to make learners start studying.

Cognitive psychologists see language learning as a psychological process through which learners construct a mental model of language system based on the interaction of cognitive knowledge and comprehensible input. Some of the technologies that are used in cognitive approaches include text - reconstruction software, concordancing software, telecommunications, and multimedia simulation software (Warschauer \& Meskill, 2000). Learners should have the opportunity to interact in an authentic social context in order to have access to comprehensible input and practice communications in which they will engage in real life (Warschauer \& Meskill, 2000). SMS is the media used in this approach. It is possible to focus on limited amount of information, since too much amount of information can be confusing and discouraging. Besides, they are encouraging to students; because they can study the lessons provided them via SMS anytime and anywhere that they prefer. What is possible through SMS is spaced presentation, which is more effective than massed presentation. According to cognitive psychologists when two presentation of a piece of information are farther apart (spaced presentation), the learners' performance on memory test is significantly better than when the two presentations are close together (Thornton \& Houser, 2005). Thornton and Houser (2005) conducted three studies in a Japanese university. They studied the effects of SMS with three groups: paper, Web and SMS in which they concluded that the effect of the frequent study was more important than the quantity of materials presented in a lesson.

\section{REWIEV OF LITERATURE}

Baleghizadeh and Oladrostam (2010) during six sessions of instruction taught three grammatical categories to participants which at the end of the experiment a grammar test was administered to both groups the result of which showed that the mobile phone SMS helped the experi- 
PAPER

Mobile Educational SMSs as Supplementary MeAns to Teach SENTENCE Paraphrasing In EMP COURSE

mental group to improve their grammatical accuracy and they performed better than the control group. The integration of mobile technologies into teaching and learning has been more gradual, as educators have sought to understand how best to use their tool to support various kind of learning. Moura and Carvalho (2010) defined "we can deliver several learning activities to students easily and immediately via SMS technology". Moreover, their findings show that students have positive perception about the use of mobile phones as a learning tool. Using mobiles for learning can assist students' motivation, encourage a sense of responsibility, help organizational skills, act as reference tools, and help track students' progress and assessment (Savill-Smith and Kent, 2003).

The effectiveness of using SMS-based mobile learning to support classroom teaching of English phrases to high school students in rural Nigeria was carried out by Nwaocha (2009). In order to determine if there were significant differences between students' success rate, pretests were administered to the experimental and control groups, after both received classroom instructions from the same instructor. Subsequently, posttests were administered to both groups, after the experimental and control groups had received SMS-based instruction and extra classroom instructions respectively. The results clearly revealed that after receiving the SMS-based instruction, the experimental group performed better than their counterparts who had received additional classroom instructions. There is considerable interest from educators and technical developers in exploiting the unique capabilities and characteristics of mobile technologies to enable new and engaging forms of learning (Naismith, Lonsdale, Vavoula, \& Sharples, 2004).

\section{RESEARCH QUESTION}

The study sets a dual goal: firstly, does supplementary syntactic SMS activity affect students' skill of sentence paraphrasing? and secondly, what are the participants attitudes toward this system?

\section{SigNifiCANCE OF RESEARCH}

While there is an extensive literature on many other aspects of language learning and teaching, particularly in classroom settings, there is few number of researches relating to the use of mobile phones and related applications and their impact on the skills like paraphrasing English sentences process. Also, constrained time of English specifically EMP classes to teach almost all language skills and sub skills at university calls for some new complementary supporting educational means. University students' digital technological experience leads to their dissatisfaction of the present type of education since it cannot touch their real world. This technology needs to be activated to have real, engaging and fruitful education. Better instructional design is needed rather than lecturing and testing education.

Despite the challenge of integrating phones into a learning environment, it has been shown that as users become more expert at using digital interfaces, their learning styles and how they perceive the learning material are both likely to change (Stockwell, 2010). Presenting smaller modular chunks - such as mini-essays and grammar quizzesmay be more suitable for better mobile phone learning experiences. Indeed, academics (Rutherford, 1987; Krashen, 1989) have long suggested that learning is enhanced when learnt in comprehensible, manageable pieces. With this in mind - and in order to address an absence of data on the development of paraphrasing sentence skills via mobile phones SMSs, this study is hoped to contribute to the literature in this respect.

\section{The EFFECT Of SMS ON Writing}

Despite the existence of studies focusing on aspects of MALL (Mobile Assisted Language Learning) in language teaching, the literature lacks sufficient research exploring the tendency of students for MALL and mobile learning tools such as SMS usage as supplementary material for writing classes in ELT (English Language Learning) and EMP courses. A few researchers and theoreticians have unanimous agreement that text messaging has a positive effect on students' writing. Jacob (2011) in his study to investigate the effect of applying SMS on note taking and comprehension of materials concluded that SMS as an educational tool improves students' note-taking competence and comprehension. Therefore, recommendations were made including the teaching and learning of strategic note taking using SMS style of writing, and that teachers should make efforts to encourage their students to write notes during lectures. Dansieh (2011) describes effect of SMS on students' written communication skills. He examines the possible impact of SMS on students' writing skills, and students and teachers' attitudes towards this activity. O'Connor (2006) studied the effect of teaching through SMS on students' writing skill and the way teachers can build on students' use of this technology. It can be helpful in improving academic performance. Venable (2012) as an English composition instructor at John Jay College incorporated SMS assignment as a complement to longer essays and papers in which students "describe the essence of the chalkboard in one or two sentences." He notes "A lot can be said with a little" and the skill that comes from practicing thoughtful, but concise writing can be applied in a variety of contexts. "He observes that with large course enrollments, SMS assignments may mean more time for attention and feedback for each student's submission (Venable 2012). It seems that texting for class purposes is generally well-received by students. AlQomoul (2011) examined the impact of applying English SMS on the improvement of the first year students' written communicative skills in Tafila Technical University. According to the findings of this study, the students improved greatly in written skills. Another study from educational researchers at Kent State University and the University of Northern Colorado, focusing specifically on the use of SMS in online courses, also found that "students were positive about receiving text messages" and that engaging in this type of communication in their courses was "a good idea as well as a useful one" (Kovalik, Hosler,2010)

\section{Methodology}

\section{A. Subjects}

Two groups (each 40-second year students of medicine) were randomly assigned to be the experimental and the conventional group studying the same syllabus materials designed for English for Medical Purposes (EMP) II course in a 17-week semester in Kashan University of Medical Sciences, Iran. 


\section{B. Procedure}

The former received supplementary SMS contents in a scheduled pattern of delivery two times a week to strengthen their learning while the latter only was taught in a face-to-face setting. The SMSs contained a short summary of syntactic points necessary to paraphrase a sentence explained in each class for all. A 20- item test was devised as a pre- test and post- tests for eliciting the subjects' knowledge of sentence paraphrasing. Qualitative data from an open questionnaire and a 12 likert -scale items indicated students' general attitudes towards receiving paraphrase syntax points via SMS.

\section{INSTRUMENTS OF STUDY}

In the present study, a questionnaire, including 12 questions, was used. The questions were to explore the attitudes of students' toward the use of SMS for EMP classes. The questions were adopted from the studies of Attewell, Savill-Smith and Douch (2009) and the studies related to literature, which included the benefits and disadvantages of MALL supplementation. This questionnaire consisted of sections including the attitudes of students towards application of SMS in EMP classes in the fields of motivation, achievement, and collaboration. To maximize the effectiveness of the study, during the procedure piloting was also an important process. Mackey and Gass (2005) express that for an effective questionnaire, the questions should be answerable, reviewed by several researchers and piloting should be done among research population. In addition, Cohen (2007) states piloting increases the reliability, validity and practicality of the questions. An open questionnaire was also given to the students to examine their feedback toward their ideas on applying the supplementary SMSs in EMP class. The computer programmer calculated questionnaires reliability. For validity, it was given to a number of professors of English language to examine them and to give comments on the questionnaire statements. Considering their comments, the questionnaire was rearranged and prepared to be employed in the student participants under investigation. To find out whether there were any significant differences before and after study, pretests and posttests were administered. Pretest and posttest questions were adopted from Wekker and Haegemen (1989).

\section{DATA ANALYZE}

In the present study, the attitudes of the students towards using supplementary SMSs were measured by using analysis of data elicited through the questionnaire given to the students. Benefits of using mobile phones for writing classes included motivation, achievement and competence, communication and collaboration. Drawbacks are included as technical problems, word limit and lack of social communication and collaboration. In the present study for the two questionnaires (12-item\&7 3item), descriptive analysis was used. To analyze pretest and posttest data paired t-test was used. Finally, the likert scale questionnaire was descriptively analyzed via SPSS (Statistical Package for the Social Sciences) 16.00 version to explore the attitudes of participants' towards the use of SMS in writing classes. SPSS program statistics included in the base software as: Descriptive statistics: Cross tabulation, Frequencies, Descriptives, Statistics: Means, Ttest, and ANOVA.

\section{FINDINGS AND DisCUSSION}

To know the impact of SMS as an instructional supplementary tool for paraphrasing English sentences and measure the attitudes of students towards this activity a questionnaire consisting 12 likert-scale items, divided into 3 sub-categories, was administered. Tables summarize the results of SPSS analysis.

\section{A. Motivation}

a) Receiving supplementary SMS-based class materials increased my motivation for sentence paraphrasing.

\begin{tabular}{|c|c|c|c|c|}
\hline $\begin{array}{l}\text { Strongly } \\
\text { disagree }\end{array}$ & Disagree & Neutral & Agree & $\begin{array}{c}\text { Strongly } \\
\text { agree }\end{array}$ \\
\hline $\begin{array}{ll}2 & 5 \% \\
\end{array}$ & $\begin{array}{ll}5 & 12.5 \%\end{array}$ & $\begin{array}{c}3 \\
7.5 \%\end{array}$ & $\begin{array}{ll}10 & 25 \% \\
\end{array}$ & $20 \quad 50 \%$ \\
\hline
\end{tabular}

b) The use of mobile phones SMSs increased my active participation both in class and outside the class.

\begin{tabular}{|c|c|c|c|c|}
\hline $\begin{array}{l}\text { Strongly } \\
\text { disagree }\end{array}$ & Disagree & Neutral & Agree & $\begin{array}{c}\text { Strongly } \\
\text { agree }\end{array}$ \\
\hline & $15 \%$ & $10 \%$ & $\begin{array}{c}5 \\
12.5 \%\end{array}$ & $\begin{array}{c}25 \\
62.5 \%\end{array}$ \\
\hline
\end{tabular}

c) The use of mobile phones during writing class was fun.

\begin{tabular}{|c|c|c|c|c|}
\hline $\begin{array}{l}\begin{array}{l}\text { Strongly } \\
\text { disagree }\end{array} \\
\end{array}$ & Disagree & Neutral & Agree & $\begin{array}{c}\text { Strongly } \\
\text { agree }\end{array}$ \\
\hline $\begin{array}{ll}5 & 12.5 \%\end{array}$ & $7 \quad 17.5 \%$ & $\begin{array}{c}7 \\
17.5 \%\end{array}$ & $\begin{array}{c}3 \\
7.5 \%\end{array}$ & $18 \quad 45 \%$ \\
\hline
\end{tabular}

d) Mobile phone increased my interest in EMP.

\begin{tabular}{|c|cc|c|c|cc}
\hline $\begin{array}{c}\text { Strongly } \\
\text { disagree }\end{array}$ & Disagree & Neutral & Agree & \multicolumn{2}{|c}{$\begin{array}{c}\text { Strongly } \\
\text { agree }\end{array}$} \\
\hline $4 \quad 10 \%$ & 2 & $5 \%$ & 1 & 3 & 30 & $75 \%$ \\
\hline
\end{tabular}

The first question is about the role of SMSsupplementary activity in increasing motivation for sentence paraphrasing. Students mostly agree with activity's increasing effect on paraphrasing as the percentages show. While the percentage of strongly agree for the first item is $50 \%$, agree has the $25 \%$ percentage which means $75 \%$ of students considered the activity increases their motivation. Most of the students thought that SMS-supplementary materials have an increasing impact on their motivation. The second item of motivation sub-category is related to increased active participation. As the second item shows, $75 \%$ of students stressed that active participation is increased by assisting role of SMS-supplementary activity whereas 10 of students did not admit that it has an increasing role. It is shown that the activity has an impact on increasing the students' active participation both in class and outside the class.

The third item includes the fun that participants had when they used mobile phones during EMP class. Twenty-one of students felt that this way of learning was fun while about half (47\%) of them considered total opposite. Increasing interest is stated in the fourth item. The majority of participants i.e. $82 \%$ believed that their interest was increased by this activity in EMP. These items have been picked to find out the effect of motivation on participants' paraphrasing activity achievement. As Dörnyei (2005) states, motivation significantly affects language learning success. Without sufficient motivation, even individuals with the most remarkable abilities cannot accomplish 
long- term goals, and neither are appropriate curricula and good teaching enough on their own to ensure student achievement. These four items show, the participants favored the messages served as learning tools. While about $78 \%$ of participants consider mobile phones increases their motivation, $21 \%$ disagrees. Therefore, there is a strong tendency towards using mobile phones for writing activities. This result is in agreement with the findings of previous studies such as Kennedy and Levy (2008), and Stockwell (2008). In addition, Jones, Edwards and Reid (2009) state that the participants who took place in their study saw SMS based instruction as an extrinsic motivator in helping them to study. They say that when the students were asked about receiving SMS from their professor, students thought the messages more effective and motivator to study.

\section{B. Achievement and Competence}

a) With mobile phone, I managed to reach a summary of class lessons from wherever I was.

\begin{tabular}{|c|c|c|c|c|}
\hline $\begin{array}{l}\text { Strongly } \\
\text { disagree }\end{array}$ & Disagree & Neutral & Agree & $\begin{array}{c}\text { Strongly } \\
\text { agree }\end{array}$ \\
\hline & $5 \%$ & $\begin{array}{c}3 \\
7.5 \%\end{array}$ & $\begin{array}{c}15 \\
37.5 \%\end{array}$ & $20 \quad 50 \%$ \\
\hline
\end{tabular}

b) It helped me go on practicing writing when I was away from class.

\begin{tabular}{|c|cc|cc|c|c|}
\hline $\begin{array}{c}\text { Strongly } \\
\text { disagree }\end{array}$ & Disagree & Neutral & Agree & $\begin{array}{c}\text { Strongly } \\
\text { agree }\end{array}$ \\
\hline $4 \quad 10 \%$ & 2 & $5 \%$ & 3 & $7.5 \%$ & $\begin{array}{c}11 \\
27 \%\end{array}$ & 20 \\
\hline
\end{tabular}

c) SMS- based sentence paraphrasing activity improved my writing skill.

\begin{tabular}{|c|cc|cc|c|c|}
\hline $\begin{array}{c}\text { Strongly } \\
\text { disagree }\end{array}$ & Disagree & Neutral & Agree & $\begin{array}{c}\text { Strongly } \\
\text { agree }\end{array}$ \\
\hline $25 \%$ & 2 & $5 \%$ & 6 & $15 \%$ & 15 & 15 \\
& & & & $37.5 \%$ & $37.5 \%$ \\
\hline
\end{tabular}

d) I can learn sentence syntax more independently when I use mobile phone.

\begin{tabular}{|c|c|c|c|c|}
\hline $\begin{array}{l}\text { Strongly } \\
\text { disagree }\end{array}$ & Disagree & Neutral & Agree & $\begin{array}{c}\begin{array}{c}\text { Strongly } \\
\text { agree }\end{array} \\
\end{array}$ \\
\hline $12.5 \%$ & $\begin{array}{ll}7 & 17.5 \%\end{array}$ & $25 \%$ & $\begin{array}{c}18 \\
45 \% \\
\end{array}$ & $\begin{array}{c}12 \\
30 \% \\
\end{array}$ \\
\hline
\end{tabular}

The second four items indicate the descriptive analysis of achievement/ competence sub-category items. The students were also given items exploring their achievement and or competence when they received complementary syntax SMSs in EMP class. The first item included the information availability. $87.5 \%$ of participants considered that they could reach information from wherever they were while 2 and 3 of them were negative and neutral respectively about this. It can be seen that via mobile phones most of the participants achieved to reach information whenever and wherever they want. Another item under the achievement subtitle was about whether mobile phones helped their learning outside the class. $77.5 \%$ of the participants reported that they agree with this. The result indicates that the participants could go on learning even if they were away from the classroom environment. The third item was related to improving writing skill by SMS based writing activity. Thirty participants believed this supplementary activity improved their writing skill whereas $10 \%$ did not believe its impact to improve writ- ing skill which shows that SMS based writing activity improved most of the participants' writing skill and increased their competence. The fourth item of this subcategory is about learning English syntax more independently by using mobile phone. As the question refers to independent learning, $75 \%$ of participants agreed with it whereas $20 \%$ disagree. So, most of the participants considered it was useful for independent learning since they can study and focus on materials on their own pace out of class.

In the light of responses given to achievement and competence items, it can be inferred that there is a common view that supplementary SMS usage in EMP classes provides the students with the feeling of achievement and competence. In this sense, the messages fulfilled their function of improving 'anytime and anywhere' learning. While most of the participants considered that mobile phone usage increased the achievement and competence in EMP class to paraphrase sentences, the others disagreed. According to Başoğlu and Akdemir (2010), using mobile phones for class activities improves students' achievement more than the traditional ways of teaching. However, in Stockwell's (2007) study investigating students' learning through either their mobile phones or personal computers indicated that mobile phones were less preferred than computers.

\section{Collaboration and Communication}

a) The use of mobile phones improved my class communication with my friends.

\begin{tabular}{|c|c|c|c|c|}
\hline $\begin{array}{l}\text { Strongly } \\
\text { disagree }\end{array}$ & Disagree & Neutral & Agree & $\begin{array}{c}\text { Strongly } \\
\text { agree }\end{array}$ \\
\hline $4 \quad 10 \%$ & $\begin{array}{ll}4 & 10 \%\end{array}$ & $2 \quad 5 \%$ & $\begin{array}{c}12 \\
30 \%\end{array}$ & $18 \quad 45 \%$ \\
\hline
\end{tabular}

b) I enjoyed receiving class lessons to communicate with my teacher.

\begin{tabular}{|c|c|c|c|c|}
\hline $\begin{array}{c}\text { Strongly } \\
\text { disagree }\end{array}$ & Disagree & Neutral & Agree & $\begin{array}{c}\text { Strongly } \\
\text { agree }\end{array}$ \\
\hline $1 \quad 2.5 \%$ & 7 & 5 & 10 & 17 \\
& $17.5 \%$ & $12.5 \%$ & $25 \%$ & $42.5 \%$ \\
\hline
\end{tabular}

c) Receiving group and similar materials via SMS made me feel more social.

\begin{tabular}{|c|c|c|c|c|}
\hline $\begin{array}{l}\text { Strongly } \\
\text { disagree }\end{array}$ & Disagree & Neutral & Agree & $\begin{array}{c}\text { Strongly } \\
\text { agree }\end{array}$ \\
\hline $10 \quad 25 \%$ & $\begin{array}{c}14 \\
35 \%\end{array}$ & $25 \%$ & $\begin{array}{c}9 \\
22.5 \%\end{array}$ & $\begin{array}{c}5 \\
12.5 \%\end{array}$ \\
\hline
\end{tabular}

d) SMS-based writing lessons helped me less anxious.

\begin{tabular}{|c|c|c|c|c|}
\hline $\begin{array}{l}\text { Strongly } \\
\text { disagree }\end{array}$ & Disagree & Neutral & Agree & $\begin{array}{c}\text { Strongly } \\
\text { agree }\end{array}$ \\
\hline י-- & $6 \quad 15 \%$ & |-----------ינ & $\begin{array}{c}9 \\
22.5 \%\end{array}$ & $25 \quad 62.5 \%$ \\
\hline
\end{tabular}

The effect of SMS-based English syntax delivery on communication and collaboration is analyzed with the last four items. The first item is related to impact of using SMS for writing activity on improved class communication with friends.

Seventy five percent of participants believed that the activity increased their class communication skill, 20\% participants did not considered it affected their communication skill in a positive way. As the analysis of the first item shows, SMS-based English syntax activity affected 
the class communication skill in a positive way, probably because they could ask and answer questions from each other in the class. The second item takes the communication with teacher as basis. Twenty-seven students enjoyed to communicate with their teacher by texting messages for SMS-based English syntax delivery activity while just 8 out of 40 participants considered that it was not a good way of communication to text messages to their teacher. As the second item shows, most of the students believed it was a useful way of learning to communicate with their teacher as an increasing effect on their communication skill. Feeling more social by the integration of mobile phone into the EMP class is focused on at the third item of collaboration and communication sub-title. It is seen that only $35 \%$ of students thought this activity made them feel more social whereas $60 \%$ of participants did not have any collaboration with others. With the percentages, it can be inferred that majority of the participants considered that to feel more social they did not need to have such a writing activity. The students usually are stressful in English classes and this causes them not to be so active in class. Having received SMS-based English syntax-based SMSs as a collection of class key point materials, students gained more self-confidence in EMP classes. It is shown in the fourth item in which $85 \%$ of students considered that these SMSs facilitated their class participation and caused them less anxious in the class activity participation. The majority $(66.5 \%)$ of the students considered that SMS-based English syntax delivery usage is necessary for collaboration and communication, while the other (34\%) students considered that to enhance communication and collaboration skill it was not necessary to integrate mobile phone into the writing classes. Collaboration is also stated as an important kind of learning in Al- Fahad's study.Al Fahad (2009) states that multimedia technologies such mobile phones or computers may facilitate collaborative learning. Attewell( 2003) also reveals that when participants use SMS they come together to share content and messages with mobile devices and in spite of the isolationist affect mobile phones they work collaboratively. In addition, Moussa (2003) states that mobile applications generally improve collaboration via real-time or instant interactivity, regardless of time and location, leading to better decision making. These benefits can prove equally useful for improving the learning environment (cited in Motiwalla, 2007, p. 585). As Franklin (2011) states not only collaboration but also communication skill is supplied by using mobile phones. He states that in today's world, the new generation believes in social networks, diversity of collaboration and mobile broadband. Besides, $90 \%$ of college population owns a mobile phone and see this phone as their single most important form of communication. They link learners in new ways to other learners and information. This constant access to information offers learners new ways learn.

An open questionnaire examines students' feedback towards their attitudes on using mobile phones in their learning in the classroom. For reliability the questionnaire was calculated by the computer programmer. For validity, the questionnaire was given to a number of professors of English language to examine them and to give comments on the questionnaire statements.

1- Do you find the use of SMS in the learning English syntax to paraphrase more helpful?
In responding to this question, $70 \%$ of the students insisted that the use of SMS makes them understand syntax tasks more. They commented that such technique (SMS) make them enhance the linguistic features. However, 30\% of the students believed this technique could not be so helpful in paraphrasing tasks.

2- Do you think that the technique of using SMS helps students overcome your anxiety in class about writing, particularly at the initial stage?

Findings of this part have indicated that $90 \%$ of the students find this technique (SMS) more enjoyable and it makes them not fearing of the linguistic features. This is because it makes the environment of the classrooms enjoyable and motivating. This technique also helps students to use English outside classroom.

3- Which do you prefer, the use of SMS, the traditional techniques (i.e. the notebooks and in class white board tasks), or both of them?

It is interesting to note that $81 \%$ of the participants preferred to use both SMS and white board activity in the language classroom; whereas, $19 \%$ of them preferred to use class work without SMS.

By administering the pretests and posttests and gathering the data, to find out whether there was any significant differences between pretests and posttests, paired- samples $\mathrm{t}$ - test was run. The results of these analyses are presented in the following tables.

TABLE I.

A.PAIRED SAMPLES STATISTICS

\begin{tabular}{|l|c|c|c|}
\hline & Mean & Std. Deviation & $\begin{array}{c}\text { Std. Error } \\
\text { Mean }\end{array}$ \\
\hline $\begin{array}{l}\text { Pair Experimental } \\
\text { learners pretest }\end{array}$ & 12.1786 & 1.82683 & .34524 \\
\hline $\begin{array}{l}\text { Experimental learners } \\
\text { posttest }\end{array}$ & 17.3571 & 2.92137 & .55209 \\
\hline $\begin{array}{l}\text { Pair 2 Conventional } \\
\text { learners pretest }\end{array}$ & 12.3704 & 2.40429 & .46271 \\
\hline $\begin{array}{l}\text { Conventional learners } \\
\text { posttest }\end{array}$ & 12.5926 & 2.32477 & .44740 \\
\hline
\end{tabular}

TABLE II.

B.PAIRED SAMPLES CORRELATION

\begin{tabular}{|l|c|c|}
\hline & Correlation & Sig. \\
\hline $\begin{array}{l}\text { Pair 1 Experimental learners } \\
\text { pretest \& Experimental learners } \\
\text { posttest }\end{array}$ & .383 & .044 \\
\hline $\begin{array}{l}\text { Pair 2 Conventional learners } \\
\text { pretest \& Conventional learners } \\
\text { posttest }\end{array}$ & .985 & .000 \\
\hline
\end{tabular}

As it is observed, the findings of this study suggest that experimental group is more efficient in developing the knowledge of English syntax for paraphrasing in learners in comparison to learning in conventional group i.e. students not receiving supplementary SMSs. An analysis of the result showed no significant difference between pretest and post-test in conventional group while there was a significant difference in the pretest and post-test, which signifies the effectiveness of using supplementary SMS applications in teaching and learning English sentence paraphrasing. 


\section{CONCLUSION AND IMPLiCATIONS}

The students in the experimental group significantly outperformed the conventional/control group in the posttest. In addition, the results indicated that students have positive attitudes toward this way of learning. So, it can be considered in academic settings to help learners in enhancing their language commands and learning process. Trusting on only one teaching medium can weaken learning while applying more than one media strengthens learning (Pavičić Takač, 2008). The result of this study revealed that learning English syntactic structures via complementary SMSs could be a considerable and useful means in paraphrasing English sentences in EFL learners. However, effective implementation of mobile learning requires a pedagogical approach, identification of specific learning needs and goals. It is implied that SMS can be a supplementary teaching tool that offers multiple learning and instructional opportunities for example, quizzes via SMS and marking with immediate feedback, classroom monitoring and control using SMS, a classroom response system using SMS as a tool for conducting language activities, learning projects integrated with more 'game' elements (Naismith et al. 2005). Therefore, teachers can utilize SMS as a supporting educational tool and opportunity to spend the constrained time of class to teaching all skills and sub skills. Students receiving short complementary lessons on their mobile phones via SMS were more enthusiastic and learned more than their counterparts in conventional group learn. As truly indicated by Hayati (2009), SMS is best regarded as a "Student Motivating System," whose mission is to encourage the students to keep in permanent touch with the language, with the teacher and with their fellow students. To avoid students' interference and disturbance while they are doing their afterschool activities, delivery scheme should be activated to adapt teachers' and students' timetables, otherwise mobile phones will be disappointing instead of being motivating. Overall, the main inhibitors for adoption of SMS in the curricula were the technological limitations, SMS word limit and not enough screen size to enter the SMS rather than a perception of the systems value.

\section{REFERENCES}

[1] Al Fahad, N. (2009). Students' attitudes and perceptions towards the effectiveness of mobile learning in King Saund University.

[2] The Turkish Online Journal of Educational Technology ,8(2),111119

[3] Al-Qomoul, M. (2011) Effectiveness of Using English SMS on the Development of the Tertiary Students" Spoken and Written Communication, European Journal of Social Science, 22 (3) pp 342-351

[4] Attewell(2003), m-Learning and Social Inclusion - Focusing on Learners and Learning, MLEARN 2003: learning with mobile devices, Available at: www.LSDA.org.uk/events/mlearn2003

[5] Attewell, J., Savill- Smith, C., \& Douch, R. (2009). The Impact of mobile learning: Examining what it means for teaching and learning

[6] Retrieved

from http://www.caryloliver.com/Library/ImpactOfMobileLearning.pdf

[7] Baleghizadeh, S., \& Oladrostam, E. (2011). The effect of mobile assisted language learning

[8] (MALL) on grammatical accuracy of EFL students. MEXTESOL Journal, 34(2). 1-10.

[9] Başoğlu, E and Akdemir, Q (2010), A Comparison of undergraduate
[10] students' English vocabulary learning: Using Mobile phones and flash cards. Turkish Online Journal of Educational Technology, 9 (3), 1-7. Retrieved From http://www.tojet.net.

[11] BenMoussa, C. (2003). Workers on the move: new opportunities through mobile commerce. Presented at the Stockholm Mobility Roundtable, May, 22-23.

[12] Cohen L., Manion, L. \& Morrison K. (2007). Research methods in education. Sixth ed. USA: Routledg

[13] Dansieh, S. Ali (2011) SMS Texting and Its potential Impacts on students" written Communication skills. International Journal of English Linguistics, 1(2) pp. 213-222 http://dx.doi.org/10.5539/ ijel.v1n2p222

[14] Dörnyei ,Z. (2005). The psychology of the language learner , individual differences in second language acquisition. London : Lawrence Erlbaum Associates.

[15] Franklin, T. (2011). Mobile learning: At the tipping point. TOJET: The Turkish Online Journal of Educational Technology, 10 (4), 261-275.

[16] Jacob, Omede (2011) Effect of training in the use of mobile phone short message service on note-taking and comprehension of students in Kogi State, Nigeria. Educational Research, 2(7) pp. 12581264.

[17] Jones, G, Edwards, G and Reid,A, (2009), How can mobile SMS communication support and enhance a first year undergraduate learning environment?,Research in Learning Technology, journal of the Association for Learning Technology (ALT) Vol 17, No 3 (2009)

[18] Hayati, A. M. (2009). M-learning. English Teaching Professional, $64,56-58$.

[19] Kovalik, Cindy L., Hosler, Kim A. (2010), Text Messaging and the Community of Inquiry in Online Courses, Journal of Online Learning and Teaching, Vol. 6, No. 2, June 2010

[20] Krashen, S. (1989). We acquire vocabulary and spelling by reading: Additional evidence for the input hypothesis. Modern Language Journal, 73, 440-464. http://dx.doi.org/10.1111/j.15404781.1989.tb05325.x

[21] Kennedy, C and Levy, M (2008), Learning Italian via mobile SMS. In: Kukulska-Hulme, A., Traxler, J. (eds), Mobile Learning: A Handbook for Educators and Trainers pp. 76-83. Routledge, London: (2005)

[22] Mackey, A. and Gass,S.M. (2005), Second Language Research, Methodology and Design, Mahwah, N.J.: Lawrence Erlbaum, ISBN 0-8058-4249-7

[23] Motiwalla, L. (2007). Mobile learning: A framework and evaluation. Computers \& Education 49, 581-596. http://dx.doi.org/10.1016/j.compedu.2005.10.011

[24] Moura, A., Carvalho , A.A. (2010). Mobile Learning: Using SMS in Educational Context. International Federation for Information Processing (IFIP) Advances in Information and Communication Technology, 324, 281-291. http://dx.doi.org/10.1007/978-3-64215378-5_27

[25] Naismith, L., Lonsdale, P., Vavoula, G., \& Sharples, M. (2004). NESTA Futurelab Report 11: Literature Review in Mobile Technologies and Learning. Bristol, UK: NESTA

[26] Naismith, L., Lonsdale, P., Vavoula, G., \& Sharples, M. (2005). Literature review in mobile technologies and

[27] learning (11). Bristol: FutureLab. Retrieved December 10, 2007, from http://www.futurelab.org.uk/download/pdfs/research/lit_reviews/f uturelab_review_11.pdf

[28] Naismith, L., Sharples, M., \& Ting, J. (2005). Evaluation of CAERUS: a Context Aware Mobile Guide. Proceedings of mLearn 2005. Retrieved January 20, 2011 from: http://www.mlearn.org.za/papers-full.html.

[29] Nwaocha, V. O. (2009). SMS-Based Mobile Learning System: a veritable Tool for English Language Education in rural Nigeria (ICTD 2010).

[30] O"Conner, (2005) Instant Messaging: Friend or Foe of Students" Writing? New Horizon for Learning. [Online] available: http: www.newhorizon.org/ strategies/ literacy, o conner, htm(May 28, 2011) 
PAPER

Mobile Educational SMSs as Supplementary MeAns to Teach SENTENCE Paraphrasing In EMP COURSE

[31] Pavičić Takač, V. (2008). Vocabulary learning strategies and foreign language acquisition. Clevedon, UK: Multilingual Matters.

[32] Rutherford, W. (1987). Second language grammar: Learning and teaching. New York, NY: Longman.

[33] Savill-Smith, C., \& Kent, P. (2003). The use of palmtop computers for learning: A review of the literature. London, UK: Learning and Skills Development Agency. Retrieved January 18, 2011, from:http://www.mlearning.org/docs/the_use_of_palmtop_comput ers_for_learning_sept03.pdf

[34] Stockwell, G. (2007). Japan vocabulary on the move: Investigating an intelligent mobile phone-based vocabulary tutor. Computer Assisted Language Learning, 20, 4, pp. $365-383$ http://dx.doi.org/10.1080/09588220701745817

[35] Stockwell, G. (2008). Investigating learner preparedness for and usage patterns of mobile learning. ReCALL, 20(3), 253-270. http://dx.doi.org/10.1017/S0958344008000232

[36] Stockwell, G. (2010). Using mobile phones for vocabulary activities: Examining the effect of the platform. Language Learning \& Technology, 14(2), 95-110. Retrieved from: http://llt.msu.edu/vol14num2/stockwell.pdf
[37] Thornton P, Houser C.(2005) 'Using mobile phones in English education in Japan'. Journal of Computer Assisted Learning, 21, (3): 217-228. http://dx.doi.org/10.1111/j.1365-2729.2005.00129.x

[38] Venable, Melissa, (2012) Teaching with Text Messages, available at http://www.onlinecollege.org/teaching-with-text-messages/

[39] Warschauer, M., \& Meskill, C. (2000). Technology and second language teaching. In J. W.

[40] Rosenthall (Ed.), Handbook of undergraduate second language education (pp. 303-318). NJ,

[41] Mahwah: Lawrence Erlbaum

[42] Wekker,H.,Haegmen,L.(1989) A Modern Course in English Syntax, Routlege.

\section{AUTHOR}

Jafar Asgari Arani is a Faculty Member of Kashan University of Medical Sciences, English Department, in Kashan, Iran.

Submitted 03 November 2015. Published as resubmitted by the authors 16 December 2015. 